\title{
PENGARUH ANALISIS FINANCIAL LEVERAGE TERHADAP PENINGKATAN EARNING PER SHARE (EPS)
}

\author{
Siti Maimunah \\ Dosen Tetap Fakultas Ekonomi Universitas Pakuan \\ Lecturer of Economic Faculty at Pakuan University \\ Niken Puspita Rahajeng \\ Mahasiswa Fakultas Ekonomi Universitas Pakuan \\ Student of Economic Faculty at Pakuan University
}

\begin{abstract}
ABSTRAK
Keuntungan pemilik perusahaan dispesifikasikan ke dalam laba untuk pemegang saham biasa atau disebut sebagai earning per share (EPS). Konsep financial leverage sangat penting untuk menunjukkan analisis keuangan dalam melihat trade off antara resiko dan tingkat keuntungan dari berbagai sudut keputusan yang terbaik. Penelitian yang dilakukan berhubungan dengan pengaruh analisis financial leverage terhadap peningkatan earning per share (EPS). Jenis penelitian ini merupakan penelitian korelasional dengan jumlah sampel sebanyak 5 perusahaan sub sektor tekstil dan garment yang terdaftar di Bursa Efek Indonesia selama periode 2010-2013. Pemilihan sampel ini dilakukan dengan metode purposive sampling, dan data yang digunakan adalah data sekunder. Proses analisis data yang dilakukan terlebih dahulu adalah uji asumsi klasik dan selanjutnya dilakukan pengujian hipotesis, dengan metode statistik yang digunakan adalah regresi linier berganda. Hasil penelitian menunjukkan bahwa secara parsial, financial leverage yang terdiri dari debt to equity ratio dan total debt to total assets ratio secara simultan tidak terdapat pengaruh yang signifikan terhadap earning per share (EPS). Hasil pengujian secara parsial menunjukkan bahwa variabel debt to equity ratio dan total debt to total assets ratio tidak terdapat pengaruh yang signifikan terhadap earning per share (EPS).
\end{abstract}

Kata kunci: financial leverage (debt to equity ratio dan total debt to total assets ratio), earning per share.

\begin{abstract}
The advantage for the owner of the company specified in the profits to holders of ordinary shares or referred to as earnings per share (EPS). The concept of financial leverage is very important to demonstrate the financial analysis in view of the trade off between risk and profitability from various angles the best decision. Research carried out related to the analysis of the effect of financial leverage on the increase in earnings per share (EPS). This type of research is a correlational study with a sample of 5 sub company of textile and garment sector which listed on the Indonesia Stock Exchange during the period 2010-2013. The sample selection was conducted by purposive sampling method and data used are secondary data. The process of data analysis done first is the classic assumption test before hypothesis test, with a statistical method used is multiple linear regression. The results showed that partially, consisting of financial leverage debt to equity ratio and total debt to total assets ratio simultaneously there is no significant effect on earnings per share (EPS). The test results show that the variable debt to equity ratio and total debt to total assets ratio there is no significant effect to earnings per share (EPS).
\end{abstract}

Keywords: financial leverage (debt to equity ratio and total debt to total assets ratio), earning per share.

\section{Pendahuluan}

Tujuan utama perusahaan pada dasarnya adalah untuk meningkatkan dan memaksimalkan keuntungan pemilik perusahaan yang tercermin dalam earning per share atau laba per lembar saham. Earning per share merupakan rasio yang menunjukkan bagian laba untuk setiap saham (Darmadji dan Fakhrudin, 2012, 154). EPS adalah bentuk pemberian keuntungan yang diberikan kepada para pemegang saham dari setiap lembar saham yang dimiliki (Irham Fahmi, 2011, 138). 
Pentingnya EPS ini membuat para manajer keuangan di suatu perusahaan mengusahakan untuk tercapainya kinerja perusahaan yang baik, khususnya dalam pemanfaatan modal atau aset perusahaan. Besar kecilnya EPS ini dipengaruhi oleh perubahan variabelvariabelnya. Secara umum ada dua faktor yang mempengaruhi besar kecilnya EPS yaitu struktur modal dan tingkat laba bersih sebelum pajak dan bunga. Kedua faktor tersebut sama-sama menekankan pada alternatif sumber pendanaan melalui hutang atau financial leverage. Lukas $(2010,236)$ menyatakan bahwa suatu perusahaan dikatakan menggunakan financial leverage jika ia membelanjai sebagian dari aktivanya dengan sekuritas yang membayar bunga yang tetap (misalnya, hutang pada bank, menerbitkan obligasi, atau saham preferen).

Konsep financial leverage sangat penting untuk menunjukkan analisis keuangan dalam melihat trade off antara risiko dan dan tingkat keuntungan dari berbagai sudut keputusan yang terbaik. Jika perusahaan menggunakan financial leverage atau hutang, perubahan pada EBIT perusahaan akan mengakibatkan perubahan yang lebih besar pada EPS atau penghasilan per lembar saham perusahaan.

Penelitian sebelumnya juga pernah dilakukan oleh Galih Prasetyo (2011) dengan judul "Pengaruh Financial Leverage, Earning Per Share (EPS) dan Dividen Per Share (DPS) terhadap harga saham ada perusahaan manufaktur yang terdaftar di Bursa Efek Indonesia Periode 2006-2009". Menyimpulkan bahwa secara parsial financial leverage tidak berpengaruh, earning per share (EPS) berpengaruh positif terhadap harga saham, sedangkan dividen per share (DPS) berpengaruh terhadap harga.
Penelitian ini bertujuan (1) untuk mengetahui dan menganalisis financial leverage pada perusahaan manufaktur yang terdaftar di Bursa Efek Indonesia tahun 2010-2013, (2) untuk mengetahui dan menganalisis earning per share pada perusahaan manufaktur yang terdaftar di Bursa Efek Indonesia tahun 2010-2013, (3) untuk mengetahui apakah financial leverage (debt to equity ratio dan total debt to total assets ratio) baik secara parsial maupun simultan berpengaruh terhadap peningkatan earning per share (EPS) pada perusahaan manufaktur sub sektor tekstil dan garment yang terdaftar di Bursa Efek Indonesia tahun 20102013.

\section{Metode Penelitian}

Metode analisis data yang digunakan dalam penelitian ini adalah deskriptif statistik yang meliputi analisis deskriptif, uji asumsi klasik, uji regresi linier berganda (statistik), pengujian hipotesis (termasuk uji parsial dan simultan) dengan bantuan SPSS versi 20.0 .

\section{Hasil dan Pembahasan}

Financial leverage merupakan kebijakan pendanaan melalui hutang dengan menanggung beban yang bersifat tetap guna meningkatkan earning per share. Financial leverage dapat diukur menggunakan rasio debt to equity ratio dan total debt to total assets ratio. Debt to equity ratio yaitu rasio untuk mengukur total liabilitas dengan total modal sendiri. Semakin tinggi rasio debt to equity ratio, semakin besar perusahaan dibiayai oleh hutang sebaliknya semakin rendah rasio debt to equity ratio, semakin rendah perusahaan dibiayai oleh hutang.

Total debt to total assets ratio yaitu rasio untuk mengukur total liabilitas dengan total aset. Semakin 
rendah rasio total debt to total assets ratio maka kinerja perusahaan akan baik.

Berdasarkan perkembangan financial leverage dapat dilihat bahwa dari ke 5 perusahaan yang dijadikan sampel cenderung tinggi kecuali perusahaan PT. Nusantara Inti Corpora, artinya financial leverage menunjukkan trend yang menurun karena perusahaan lebih besar menggunakan hutang untuk membiayai aktivitas operasionalnya. Kondisi ini menunjukkan adanya risiko yang tinggi untuk menanggung beban bunga tetap dan penurunan kinerja dalam menghasilkan laba.

Berdasarkan perhitungan dapat dilihat bahwa earning per share mengalami trend yang menurun karena pada tahun 2010-2013 perusahaan cenderung mendapatkan rugi per lembar saham, artinya kondisi ini dapat mempengaruhi harga saham dan return perusahaan itu sendiri. Apabila perusahaan mendapatkan rugi per lembar saham maka harga saham pun rendah dan return juga mengalami penurunan. Sebaliknya jika perusahaan mendapatkan earning per share yan tinggi maka harga saham pun tinggi dan return juga mengalami peningkatan.

Berdasarkan hasil penelitian diperoleh hasil bahwa telah terpenuhi semua uji asumsi klasik, maka dapat dilakukan pengujian selanjutnya yaitu:

1. Analisis Regresi Linier Berganda Regresi linier berganda dilakukan untuk mengetahui pengaruh variabel bebas yakni debt to equity ratio dan total debt to total assets ratio pada earning per share (EPS).

Berdasarkan hasil analisis regresi linier berganda diperoleh persamaan sebagai berikut :

$$
\begin{aligned}
& Y=a+b_{1} X_{1}+b_{2} X_{2}+e \\
& Y=82,577-1,141 X_{1}-200,431 \\
& X_{2}
\end{aligned}
$$

Hasil persamaan regresi liniear berganda dapat diuraikan sebagai berikut :

a. Konstanta (a) sebesar 82,577 menyatakan bahwa jika nilai debt to equity ratio (DER) dan total debt to total assets ratio adalah nol, maka earning per share (EPS) yang terjadi adalah sebesar 82,577 satuan.

b. Koefisien regresi $X_{1} \quad\left(b_{1}\right)$ variabel debt to equity ratio adalah negatif sebesar 1,141 menyatakan bahwa setiap penambahan 1 satuan DER akan menurunkan EPS sebesar 1,141 satuan dengan asumsi variabel lain tetap.

c. Koefisien regresi $\mathrm{X}_{2} \quad\left(\mathrm{~b}_{2}\right)$ variabel total debt to total assets ratio adalah negatif sebesar 200,431 menyatakan bahwa setiap penambahan 1 satuan total debt to total assets ratio akan menurunkan EPS sebesar 200,431 satuan dengan asumsi variabel lain tetap.

2. Pengujian Hipotesis

a. Pengujian Hipotesis Parsial (Uji-t)

Digunakan untuk menguji koefisien regresi secara individual. Pengujian ini dilakukan untuk mengetahui apakah secara parsial masing-masing variabel bebas mempunyai pengaruh signifikan atau tidak terhadap variabel terikat. Berdasarkan perhitungan diperoleh hasil uji t sebagai berikut :

1) Nilai thitung variabel debt to equity ratio (DER) sebesar $-0,343$ 
dan nilai $t_{\text {tabel }}$ bernilai 2,109 , sehingga $t_{\text {hitung }}<$ $\mathrm{t}_{\text {tabel }} \quad(-0,343<2,109)$ dan nilai signifikan $0,736>0,05$ dan memiliki nilai koefisien regresi 1,141, sehingga dapat disimpulkan bahwa variabel DER tidak terdapat pengaruh yang signifikan terhadap variabel earning per share pada perusahaan manufaktur sub sektor tekstil dan garment yang terdaftar di Bursa Efek Indonesia.

2) Nilai thitung variabel total debt to total asset ratio sebesar -1,391 dan nilai $t_{\text {tabel }}$ bernilai 2,109 , sehingga $t_{\text {hitung }}<$ $\mathrm{t}_{\text {tabel }} \quad(-1,391<2,109)$ dan nilai signifikan 0,182> 0,05 dan memiliki nilai koefisien regresi 200,431, sehingga dapat disimpulkan bahwa variabel total debt to total asset ratio tidak terdapat pengaruh yang signifikan terhadap variabel earning per share pada perusahaan manufaktur sub sektor tekstil dan garment yang terdaftar di Bursa Efek.

b. Pengujian

Hipotesis

Simultan (Uji F)

Pengujian ini

dilakukan untuk mengetahui apakah semua variabel bebas, yaitu debt to equity ratio dan total debt to total assets ratio, secara simultan dapat diterima menjadi model penelitian terhadap variabel terikat, yaitu earning per share (EPS).

Dari hasil uji ANOVA

(Analysis of Variance) didapat F-hitung sebesar 0,982 dengan tingkat signifikan sebesar 0,395. Sedangkan F-tabel diketahui sebesar 3,59. Berdasarkan hasil tersebut dapat diketahui F-hitung < F-tabel $(0,982<$ 3,59) maka $\mathrm{H}_{1}$ ditolak $\left(\mathrm{H}_{\mathrm{o}}\right.$ diterima) dan tingkat signifikannya $0,395>0,05$. Jadi dapat disimpulkan bahwa financial leverage tidak terdapat pengaruh yang signifikan secara bersamasama terhadap peningkatan earning per share pada perusahaan manufaktur sub sektor tekstil dan garment yang terdaftar di BEI tahun 2010-2013.

\section{Kesimpulan}

Dari hasil pengujian hipotesis secara parsial diketahui bahwa variabel DER tidak terdapat pengaruh yang signifikan terhadap variabel earning per share pada perusahaan manufaktur sub sektor tekstil dan garment yang terdaftar di Bursa Efek Indonesia. Sedangkan variabel total debt to total asset ratio tidak terdapat pengaruh yang signifikan terhadap variabel earning per share pada perusahaan manufaktur sub sektor tekstil dan garment yang terdaftar di Bursa Efek

Pada hasil pengujian hipotesis secara simultan diketahui bahwa financial leverage tidak terdapat pengaruh yang signifikan secara bersama-sama terhadap peningkatan earning per share pada perusahaan 
manufaktur sub sektor tekstil dan garment yang terdaftar di BEI tahun 2010-2013.

Hasil penelitian ini menunjukan tidak adanya pengaruh terhadap variabel yang ditentukan yang mana asumsi awal penelitian menyatakan bahwa financial leverage mempunyai pengaruh terhadap peningkatan earning per share pada perusahaan manufaktur sub sektor tekstil dan garment yang terdaftar di BEI.

\section{Daftar Pustaka}

Brigham, Eugene F. Dan Houston F.Joel. 2010. Manajemen Keuangan. Buku satu. Edisi Kesebelas. Jakarta : Salemba Empat.

Brigham, Eugene F. Dan Houston F.Joel. 2011. Manajemen Keuangan. Buku dua. Edisi Kesebelas. Jakarta : Salemba Empat.

Dantes, Nyoman. 2012. Metode Penelitian, Andi Offset, Jakarta.

Darsono Prawironegoro 2010.Manajemen Keuangan, Nusantara Consulting, Jakarta.

Dermawan Sjahrial. 2012. Pengantar Manajemen Keuangan. Edisi Keempat, Mitra Wacana Media, Jakarta.

Eduardus Tendelilin. 2010. Portofolio dan Investasi : Teori \& Aplikasi, BPFE UGM, Yogyakarta.

Harahap, Sofyan Syafri. 2010. Analisis Kritis Atas Laporan Keuangan, PT. Raja Grafindo Persada, Jakarta.

Hery. 2013. Akuntansi Keuangan Menengah, Center of Academic Publishing Service, Yogyakarta.

Ikatan Akuntan Indonesia. 2009. Standar Akuntansi Keuangan. Edisi 2009, Penerbit Salemba Empat, Jakarta.

Irham Fahmi . 2011. Analisis Laporan Keuangan. Edisi 1, Alfabeta, Bandung.

Kamaludin dan Rini Indriani. 2012. Manajemen Keuangan : Konsep
Dasar dan Penerapannya. Edisi Revisi, Mandar Maju, Bandung.

Kasmir. 2008. Analisis Laporan Keuangan, PT. Rajawali Pers, Jakarta.

Kasmir. 2011. Manajemen Perbankan, PT. Raja Grafindo Persada, Jakarta.

Kasmir. 2012. Analisis Laporan Keuangan, PT. Raja Grafindo Persada, Jakarta.

Keown, Arthur J., John D. Martin, J.William Petty dan David F. Scott, Jr. 2010. Manajemen Keuangan. Buku Dua. Edisi Kesepuluh. Jakarta : PT. Index.

Lukas Setia Atmaja. 2010. Teori dan Praktik Manajemen Keuangan, Andi Offset, Yogyakarta.

Martono dan D.Agus Harjito. 2011. Manajemen Keuangan. Edisi Kedua, Ekonisia. Yogyakarta.

S. Munawir. 2010. Analisa Laporan Keuangan. Edisi Empat, Liberty. Yogyakarta.

Sri Hermuningsih. 2012. Pengantar Pasar Modal Indonesia. Edisi Kelima, UPP STIM YKPN, Yogyakarta.

Suad Husnan dan Enny Pudjiastuti. 2012. Dasar-dasar Manajemen Keuangan. Buku Satu. Edisi Keenam, UPP STIM YKPN, Yogyakarta.

Sudaryono. 2011. Statistika Probabilitas : Teori \& Aplikasi, Andi Offset, Yogyakarta.

Sugiyono. 2009. Metode Penelitian Bisnis. Bandung : Alfabeta.

Sugiyono. 2012. Metode Penelitian Kombinasi. Bandung : Alfabeta.

Suharsimi Arikunto. 2010. Prosedur Penelitian : Suatu Pendekatan Praktis. Edisi Revisi, Rineka Cipta, Jakarta.

Sutrisno. 2013. Manajemen Keuangan : Teori Konsep \& Aplikasi. Yogyakarta : Ekonisia FE UII. 
Tjiptono Darmadji dan Hendy M.

Fakhruddin . 2012. Pasar Modal di Indonesia Pendekatan Tanya Jawab, Salemba, Jakarta.

Weston J.F dan Copeland, Thomas E. 2010. Manajemen Keuangan. Edisi Revisi. Jakarta : Binarup[a Aksara.

Wild, John J, K. R. Subramanyam dan Robert F. Halsey. 2008. Analisis Laporan Keuangan. Buku Satu, Salemba Empat, Jakarta. 